Teachers' beliefs about inquiry-based learning and its impact on formative assessment practice

\author{
Catarina F. Correia* and Chris Harrison
}

School of Education, Communication, and Society, King's College London, London, United Kingdom

*corresponding author

King's College London - School of Education, Communication, and Society.

Waterloo Bridge Wing, Franklin-Wilkins Building, Waterloo Road SE1 9NH London;

United Kingdom

Email: catarina.correia@kcl.ac.uk 


\section{Teachers' beliefs about inquiry-based learning and its impact on formative assessment practice}

Inquiry pedagogy has been advocated as means to engage and motivate students to learn science. The development of teacher formative assessment practice in inquiry is key for a successful implementation of student-centered inquiry pedagogy in the classroom. This study explores secondary science teachers' espoused beliefs about inquiry-based learning and the impact this has on their actual formative assessment practice in the classroom. The study provides two case studies of developing practice as teachers attempt to move towards studentcentred inquiry approaches. The study combines teacher semi-structured interviews, recordings of teacher-student(s) conversations in inquiry lessons, and field notes of classroom observations. Following a qualitative approach, we did a thematic analysis of teacher interviews to infer teachers' espoused beliefs about inquiry-based learning and about their perceptions of their role as teachers in inquiry lessons. We used a combination of the ESRU model (Ruiz-Primo and Furtak, 2007) and Torrance and Pryor (2001) framework of Convergent and Divergent assessment practices to characterise teachers' formative assessment conversations with their students in inquiry lessons. Our findings show that teachers' beliefs about inquiry are consistent with how they teach and assess inquiry, and that the promotion of student autonomy is influenced by teacher

beliefs. Teachers who position themselves as facilitators adopt more open guided inquiry approaches, while teachers who position themselves as 'shepherds' adopt more directed approaches to inquiry. This has important implications for students' autonomy and self-regulation in inquiry lessons.

Keywords: inquiry-based learning; attitudes and beliefs; formative assessment; teacher professional development

Word count: 10822

\section{Introduction}

Inquiry has been advocated as a pedagogical approach to motivate and stimulate students' interest in science, to support the development of inquiry skills and conceptual 
understanding, and to motivate teachers in teaching science and about the nature of science (Minner, Levy, and Century 2010).

Teacher adoption of inquiry pedagogy seems to be driven by three factors: curriculum, assessment, and teacher education (ESTABLISH 2011). Several European Union (EU) funded projects such as ESTABLISH, Fibonacci, and MASCIL have focused on the creation of inquiry teaching and learning materials and teacher education. However the assessment of inquiry was not taken into account (Author 2014) and assessment has a strong impact on both what is taught and how it is taught (Harlen 2007). While you can quite meaningfully test conceptual knowledge via tests, assessment of inquiry requires a more sociocultural oriented assessment formats (Dolin and Krogh 2010) that can assess competencies and skills as well as conceptual knowledge. As a consequence, until recently, teachers who adopted an inquiry approach were not provided with tools and support for how to assess inquiry and so were left to their own devices. In English schools, because the high stakes assessments focus on a test approach to science content, many teachers have had little need or experience of classroom assessment other than using test questions. This has contributed to a misalignment between curriculum and pedagogy, because the assessment methods at national level are not suited to inquiry pedagogy.

Strategies for Assessment of Inquiry Learning in Science (SAILS) and Assess Inquiry in Science, Technology, and Mathematics Education (ASSISTME) are two EU funded projects that focused on strengthening teachers' confidence in adopting inquiry pedagogy and assessing inquiry skills. Through a collaborative approach with teachers, the projects developed and trialled a range of activities for promoting inquiry-based learning and an assessment approach that is focused on the collection of learning evidence during the inquiry activity. The aim is to help teachers place formative 
assessment at the core of their interaction with their students, focusing on assessing as the inquiry evolves rather than on assessing inquiry products. This strategy provides teachers with a rich-bed of data that will enable them to decide on the next-steps to support students' learning (Author 2014).

\section{Purpose}

This study is situated within the UK ASSISTME project and reports on how teachers' beliefs about inquiry and their role as teachers within inquiry influence their actual formative assessment practice in the classroom. The findings highlight that teacher perceptions on inquiry and teacher role in inquiry shape the way they guide their students in inquiry science lessons, and also how teachers create opportunities for promoting learning autonomy and self-regulation in students.

Several studies have informed researchers and practitioners alike on the influence of internal beliefs and external pressures in adopting inquiry pedagogy (e.g. see Wallace and Kang 2004). Roehring and Luft (2004) showed how beginning teachers' understanding of scientific inquiry, content knowledge, pedagogical content knowledge, teaching beliefs, and concerns about management and students had an impact on how they adopted and facilitated inquiry in the classroom. Crawford has conducted several studies on the influence of pre- and in-service teachers' views on inquiry and how that affects their actual classroom practices in inquiry science lessons. Her findings reveal the complexity of having to negotiate with tensions between existing beliefs and new ideas on inquiry whilst developing their inquiry teaching practices (e.g. Crawford 2000; Crawford 2007). Nevertheless, very little is known, on how factors such as teachers' beliefs about inquiry influence actual assessment practices in inquiry lessons. 
Teacher practice is best understood by combining self-reported accounts of beliefs and practice with field observations of actual practice (Bryan 2003). On the one hand, teacher self-reported accounts of practice are a reconstruction of an individuals' experiences seen through the lens of an individual's knowledge, perceptions, beliefs, and reflections. On the other hand, the observations of actual practice, made by an external observer, are accounts of observed events situated in particular context/s and interpreted through a different set of lenses. As such, both self-reported accounts and observations of actual practice provide a more holistic snapshot of practice. Therefore, in order to gain a better understanding of teachers' assessment practices in inquiry and on how teachers can be best supported to develop these practices, both self-reports and external observations of practice should be taken into account.

In view of this, in this study we address the following research questions:

1. What are the teachers' espoused beliefs about inquiry-based learning?

2. What are the features of teachers' classroom assessment practices in relation to inquiry?

2. How do these espoused beliefs influence teachers' assessment practices observed in the classroom?

\section{Theoretical background}

From a theoretical perspective, this study draws on three different fields of knowledge in educational research. The section on inquiry-based learning provides an anchor to characterise teachers' practices in the context of inquiry pedagogy and theorises on how different practices promote or hinder student autonomy and self-regulation. The section on teacher beliefs and their influence on behaviour presents a framework to identify teachers' espoused beliefs and theorises on how these beliefs have an impact on 
teaching practice. Finally, the formative assessment section offers a way to conceptualise the core elements of pedagogy that support and advance students' learning, autonomy, and self-regulation.

\section{Inquiry-based learning}

In the context of science education, the term inquiry has been used in reference to three distinct categories of activities: what scientists do; how students learn; and a pedagogical approach that teachers employ (Minner, Levy, and Century 2010). In inquiry lessons, students engage in questioning, reasoning, observing, conjecturing, data gathering and interpreting, investigative practical work and collaborative discussions, and working with problems from and applicable to real-life contexts (Anderson 2002).

The opportunities for learning that arise from inquiry activities depend on the type of inquiry activity that is chosen, and on how it is planned and enacted in the classroom. Wenning $(2005,2007)$ classifies inquiry activities as guided-, bounded-, and freeinquiry, depending on whether the teacher, the students or both teacher and students make decisions about how the inquiry is carried out in the classroom. On one end of this continuum is guided-inquiry which is characterised by the teacher identifying the problem to be researched and giving extensive pre-laboratory orientation to students to design the investigation. On the other end of the inquiry continuum is free-inquiry which is characterised by students identifying the problem to be researched and developing their own experimental design. Wenning (2007) proposes that these different types of inquiry can be sequenced so as to provide a learning progression towards a higher degree of student autonomy and self-regulated learning with higher levels of intellectual sophistication. Free-inquiry activities are often described as open-ended and student-led inquiry, where students are encouraged to explore and engage with their own ideas and 
those of their peers as they work collaboratively with other students throughout the inquiry process (Wenning 2005).

Any inquiry activity can be designed to allow more or less freedom for students to make choices regarding the next steps to be taken in the inquiry process. Choice about design and implementation of an inquiry activity clearly sits with the teacher. The ways in which these teachers introduce and organise inquiry in their classrooms affects the degree of autonomy and choice that the learner is allowed to exhibit within the inquiry activity.

Several studies have shown that teaching inquiry is challenging for pre-service (Crawford 2007) and experienced teachers alike (Capps and Crawford 2013). Several factors have been put forward to account for this. According to Wallace and Kang (2004), internal factors such as teachers' beliefs about inquiry, teachers' content knowledge (CK), and pedagogical content knowledge (PCK) play a part on teacher adoption of inquiry pedagogy. For the same authors, external factors also play a part, such as the educational culture imposed by government and schools' policies, as well as time, curriculum and accountability pressures imposed by the educational system. Their findings suggest that some sets of beliefs promote inquiry, and others limit inquiry. The beliefs that promote inquiry tended to be of a private nature and centred around teacher's individual views about what successful learning in science is, and the purposes of practical work in science. As an example, inquiry fosters independent thinking and problem solving. The beliefs that limited inquiry tended to be of a cultural nature and centred around school culture. An example of this is that laboratory classes (practical work) is expendable when time is limited to cover curriculum, and/or prepare for examinations. 


\section{Teacher beliefs and their influence on behaviour}

Teachers rely on their core beliefs system when it comes to classroom practice (Nespor 1987). Psychologists characterise beliefs as complex mental constructs that influence behaviour (Pajares 1992). Beliefs cannot be directly observed or measured and therefore they can only be inferred from what people say and do (Pajares 1992). Researchers have addressed this by making a distinction between espoused beliefs (interpreted from selfreported claims) and inferred beliefs (interpreted from observation of teachers' practice) (Bryan 2012).

Bryan (2012) says that 'beliefs are far more influential than knowledge in discerning how individuals frame and organise tasks and problems and are stronger predictors of behaviour' (Bryan 2012, 479). Beliefs strongly influence perception and typically lead to self-fulfilling prophecies, often influencing behaviour in a way that will reinforce that same belief (Pajares 1992). This suggests that change in classroom practice is potentially difficult, unless teachers change their beliefs or change the way in which they interpret the events in their classroom within these belief sets.

Although the literature suggests that there are strong links between teacher beliefs and classroom practices, the relation between them is not linear. Lederman and Zeidler (1987) studied how teachers' conceptions about the nature of science (NoS) influenced teachers' classroom behaviour. They found that there was no direct influence of conceptions of NoS on teaching behaviour. There were even instances where there were inconsistencies between teachers' conceptions and their actual practice. These findings suggest that other factors might be at play, such as how subject knowledge intersects with teachers' PCK regarding teaching about the NoS, and how PCK then gets translated into actual classroom practice. 


\section{Formative assessment and informal assessment conversations}

Black and Wiliam's (1998) seminal work indicated that formative assessment offers great potential to support student learning and the development of varied competences crucial for learning, such as articulation and communication of ideas, metacognition, and selfregulation. Formative assessment is a way of conceptualising the advancement of learning through responsive teaching practices, where feedback loops between learners and with their teacher guide future thinking and action (Black and Wiliam 2009; Author 2015). Such practice is enabled through collecting evidence of learning, interpreting that evidence against short and long-term goals and making real-time decisions on the best ways to support students in bridging the gap between where they are in their learning and where they want to go (Black, Harrison, Lee, Marshall, and Wiliam 2003; Black and Wiliam 2009; Black and Wiliam 2018).

Assessment practices in the context of inquiry are influenced by the tensions experienced by teachers as they assess inquiry competences. Author (2014) reported on teachers' perceptions of gaining richer evidence of students' learning when they collected evidence during inquiry activities rather than from written reports. Teachers also reported on concerns and experienced dilemmas from enacting formative assessment in real time, such as the impossibility of collecting data about every student and about how students working collaboratively may affect individual performance, and how these aspects would affect the reliability of the teacher's assessment judgements (Author 2014). As teachers begin to change the ways in which they collect evidence of learning and make decisions about future learning, they begin to question both the processes they use, how such changes might be viewed by peers and other stakeholders and also how their beliefs about teaching and learning fit with these new assessment regimes. 
There are multiple ways that teachers use to collect evidence of learning - these range from tests, reviewing work in students' books to observing students completing activities in the classroom. In inquiry learning, teachers often focus on assessing during the inquiry activity through observation and listening in to student talk (Author 2014). In the context of this study we focus on the use of assessment conversations, in particular informal assessment conversations that take place during inquiry activities in the classroom (Shavelson et al. 2008). These conversations provide valuable opportunities for teachers to probe students' thinking and collect valuable real-time information on where students are in terms of their learning. They offer ample opportunities for real time feedback (Ruiz-Primo and Furtak 2007). Acting on evidence collected in these assessment conversations is challenging for teachers as they require a quick interpretation of evidence and appropriate decision making in very short time scales. Over time, teachers develop an intuitive practice that grows as they experience more and more of these situations (Black, Harrison, Lee, Marshall, and Wiliam 2003; Heritage 2007).

\section{Methods}

The study presented here is part of a larger study conducted in the UK under the EU funded project ASSISTME. The large study involved eleven teachers (four primary, four secondary science and three secondary mathematics teachers) who were developing their teaching and assessment practices in inquiry. The larger study investigated how teachers facilitated informal assessment conversations for formative purposes. Studying teachers' developing practice moving towards student-centred inquiry is important because this type of practice is not yet common in English science classrooms (Author 2014), and there is evidence that supports its positive impact on student engagement, motivation, and learning (Minner, Century, and Levy 2010). 
The four science teachers were all experienced teachers, ranging from 10-35 years service and had all been working on developing their inquiry pedagogy (participating on the SAILS project) for at least two years prior to their involvement with the ASSISTME project. For this project, they attended a total of seven teacherresearcher meetings between October 2014 and December 2015. The meetings took place approximately every 2-3 months and had a duration of half-day to one full day. These meetings were focused on activities promoting reflective discussions about inquiry pedagogy and assessment, about design and revision of inquiry activities and assessment tools, and about teachers reporting back on their experiences of trialling the inquiry activities and assessment tools with some of their classes. During these sessions we collected teacher artefacts (written reflections and lesson plans), and audiorecordings and field notes of the discussion from each meeting. All teachers enacted at least one, sometimes two, new inquiry lessons every term of the academic year of 2014/15 and would report back on their trials on the teacher-researcher meeting days. The lessons were designed to enable the teachers to capture evidence of student learning during the inquiry process through informal assessment conversations either as part of the inquiry activity or from plenaries and reflections on how the inquiry was progressing.

We conducted an exploratory analysis of all data concerning the four science teachers. Our aim was to gain better understanding of each teacher's practice in light of their self-reported perceptions on inquiry pedagogy, their assessment practice and teacher role in inquiry and our observations of their assessment and teaching practice, and how these teachers compared with one another.

The exploratory analysis showed two distinct teaching and assessment practice profiles: two teachers whose self-reported perceptions of practice and observed practices 
where congruent with student-led free inquiry; and two teachers whose self-reported perceptions of practice and observed practice were more congruent with a teachercentered guided approach, but where there were instances suggesting attempts to move towards student-led free inquiry. In this study we choose to do an in-depth exploration of the latter by focusing on the two teachers whose developing practice seems to be moving from a more teacher-centered and guided approach to inquiry towards a more student-led free inquiry approach .Our aim is here to investigate how teacher espoused beliefs about inquiry-based learning shape the way these teachers set up and facilitated informal assessment conversations during inquiry lessons. We believe that this can provide us with a valuable insight into this type of developing practice and the ways in which teachers in these situations can be best supported.

\section{Sample and design}

Our teachers where Jane (female) and James (male), who are two secondary science teachers with 13 and 34 years of teaching experience, respectively. At the time of the study they were Heads of Science at their schools. Jane and James subject specialisms are chemistry and physics, respectively. Jane taught in a girls' comprehensive school and James taught in mixed comprehensive school, both located in the south of England. Jane's lessons involved a group of Year 11 (15-16 years old) students with high attainment levels. James's observed lessons involved a group of Year 10 (14-15 years old) students with mixed attainment levels. For this part of the study, a total of four lessons were observed, two lessons for each teacher (details presented in Table 1). Although four lessons might be considered to be a small data set, it enabled us to analyse a total of eighteen informal assessment conversations. From the classroom observations we have collected full lesson length audio-recordings complemented by 
field notes of classroom observations for each lesson. To record teacher-student dialogue, teachers wore a small lapel omni directional microphones. Students' consent was sought, and students were informed that teachers were carrying these microphones and that the recordings would be used to inform, develop and improve teaching practice. We have also collected a total of four audio recordings of semi-structured post-lesson teacher interviews.

[Table 1 near here]

\section{Limitations in the design}

Investigating teachers' practices in the classroom implies studying practices that are situated in a given socio-cultural context (Lave 2009). Teacher expectations about student learning affect teachers' instructional practices and the socioemotional environments of the classroom (Rubie-Davies 2007). For this reason, we chose to focus our attention on lessons that involved the same group of students for each teacher, and we chose topics where teachers reported to be confident in. The electromagnets inquiry lesson plan was the same for both teachers. The other two inquiries (how is electromagnetism generated and factors affecting the stability of a double decker bus) were conducted by only one of the teachers. We are aware that the following factors may have an impact on the comparison of practices of these two teachers: number of lessons observed; different topics (for one of two lessons for each teacher); and having two classes with different attainment levels. However, we assume that teachers' espoused beliefs about inquiry and their role in teaching and assessing inquiry are among the main drivers in shaping these teachers' practice in the context of informal assessment conversations, and we hypothesise little variation in teachers' practice 
across their interaction with different groups of students. This assumption is based on our exploration, for these same teachers, of other lesson observations and post-lesson interviews with other groups of students, in the larger study (not reported here).

In this study we do not presume to make generalisations on practice and we acknowledge the inherent complexity of practice being situated in a socio-cultural context. Our aim is to illustrate and argue for how, in specific contexts, these teachers' espoused beliefs about inquiry seem to influence how they engage with and facilitate informal assessment conversations with their students.

\section{Data analysis}

The data analysis was conducted using two independent data sets. Data set 1 grouped teacher self-reported information gathered from four post-lesson teacher interviews (two for each teacher) and from seven reflective group discussions on teacher-researcher meeting days. This data set was used to identify teachers' espoused beliefs about inquiry-based learning. Data set 2 grouped audio-recordings and field notes gathered from four classroom observations (two for each teacher). This data set was used to characterise teacher-student informal assessment conversations and to draw inferences regarding the formative assessment practices of each teacher.

\section{Identifying teachers' espoused beliefs about inquiry-based learning}

The audio-recordings from data set 1 (post-lesson interviews and group discussions at teacher-researcher meeting days) were transcribed verbatim. The data were analysed qualitatively through content analysis (Cohen, Manion, and Morrison 2011, 561). The data were summarised for each teacher under four themes, as follows: definitions of inquiry-based learning, descriptions on how learning takes place in inquiry lessons, the 
role of the teacher in inquiry, and teacher self-reported teaching and assessment practices in inquiry.

The summaries formed the basis for identifying teachers' espoused beliefs in relation to the four themes presented above. To identify teachers' espoused beliefs we used Bryan’s (2003) definition 'beliefs are psychological constructions that (a) include understandings, assumptions, images, or propositions that are felt to be true ... (c) have highly variable and uncertain linkages to personal, episodic, and emotional experiences' (Bryan 2003, 837). The summaries were discussed with the other author (using examples from the data) to ensure agreement in the interpretation of teachers' espoused beliefs arising from the data.

Characterising informal assessment conversations and drawing inferences on practice Informal assessment conversations (Shavelson et al. 2008) were identified as all instances in the lesson where the teacher and students engaged in informal conversations whose conversational pattern involved more than three sequential speaking turns between the teacher and one or more students. This enabled us to separate these informal discussions from the typical initiation-response-feedback (evaluation) interactions (Mehan 1979). We have analysed a total of eighteen of thirtyone assessment conversations. These were selected as being representative of the whole sample in terms of focus on content and epistemic knowledge and/or skills, and teacher actions (e.g. types of questioning).

The transcripts from classroom assessment dialogue (nine conversations for each teacher) were coded using a combination the ESRU model developed by Ruiz-Primo and Furtak (2007), and an adaptation of Torrance and Pryor's (2001) 
Convergent/Divergent formative assessment framework and Alexander's (2006) characterisation of classroom dialogue.

The ESRU model enabled a characterisation of the teacher's contribution to the discussion in terms of gathering information from students (eliciting) and using it to help students move towards learning goals. The ESRU model is geared to identify feedback loops and characterises assessment conversations using four main categories which are teacher Elicits (E), Student responds (S), teacher Recognizes (R), and teacher Uses (U). Eliciting is associated with to all instances when the teacher creates an opportunity to collect evidence of learning. Recognizing concerns all instances when the teacher repeats or rephrases student utterances. Using describes all instances when the teacher creates an opportunity to make use of the learning evidence to support learning (e.g. ask a follow up question). The ESRU main categories were applied to each speaking turn (one speaking turn is defined as the non-interrupted speech utterances of one single individual, this could be either the teacher or student). One speaking turn can include more than one ESRU code.

We used an adaptation of Torrance and Pryor (2001) Convergent/Divergent assessment framework and Alexander's (2006) categorization of classroom dialogue to draw inferences on the purpose behind teacher guidance during inquiry activities. The work of Torrance and Pryor (2001) formed a basis for two categories to describe teachers' use of questions or follow up comments. Teacher Divergent talk (TD) refers to all instances in the dialogue where the teacher asks questions to probe and encourage students' thinking and to promote discussion. Teacher Convergent talk (TC) refers to all instances in the dialogue where the teacher asks questions to check if students are on an intended path, and if they know something. Alexander's (2006) description of instances of exposition and instruction in classroom dialogue, were used to develop yet two more 
categories that describe teacher feedback. Teacher Lectures (TL) refers to all instances in the dialogue where the teacher provides information through exposition or direct instruction. Teacher Affirms (TA) refers to all instances in the dialogue where the teacher repeats or reformulates students' contributions. All four categories form the teacher guidance coding system. The codes are mutually exclusive and were used to code each speaking turn. Coded examples (using ESRU and teacher guidance coding system) are presented in Table 2 . The sequence of the codes that emerged from each assessment conversation was recorded and analysed for recurrent patterns on teacher practice.

[Table 2 near here]

\section{Inter-rater reliability}

The inter-rater reliability was calculated for the application of ESRU and teacher guidance coding systems described above. We developed a coding manual for each coding system including for each code: code name, code description, and an example of code attribution. The coding manual was then used by two researchers to independently code the data. Disagreements in the coding were then discussed and where possible consensus in attribution was reached. The inter-rater values presented here refer to the agreement percentages after the coding discussions took place.

For the ESRU codes, we calculated the inter-rater agreement for the E, R, and $\mathrm{U}$ codes which were used to characterise teacher's actions. The S code (student responds to teacher question/comment) posed no ambiguity in attribution, and therefore was not considered. We coded approximately five percent $(\mathrm{N}=87)$ of the whole coded data set from the larger study. The percentage of inter-rater agreement using E, R, and U codes 
is 90.8 . For the teacher guidance codes, we coded approximately five percent $(\mathrm{N}=92)$ of the whole coded data set from the larger study. The percentage of inter-rater agreement for teacher guidance codes was 88.0

\section{Results}

In this section we present the findings for both teachers. For sake of clarity, these are organised for each teacher in two sub-sections as follows: teacher espoused beliefs (related to first research question) and features of classroom assessment practices (related to second research question).

\section{Jane's espoused beliefs}

Jane's perception of inquiry in science suggests an espoused belief in an apprenticeship model in which students engage in scientific practices experiencing what real scientists do. In other words, teaching through and about inquiry is about educating students to be become scientists.

I think a lot of us fall into the trap of developing scientific knowledge as opposed to developing those behaviours and thinking explicitly about what they are doing and why they are doing it, and how they are going to improve .... and that is what scientists do. Give them [students] autonomy to develop their own investigations. (Taken from an interview with Jane, October 2015)

She perceives students' learning through inquiry as what seems to be a process of educated-guess trial and error. Jane's role as a teacher is to monitor when students are learning and to get them to reflect on what they are doing and why. This implies not giving answers away to students but instead supporting them in developing competences that will enable them to seek those answers by themselves. This suggests that Jane is adopting a "facilitator" role.

The most valuable is having conversations with students and asking them why have you made that particular decision? how are you going to measure that? 
...that leads them [students] to question their own practice and change it themselves. (Taken from an interview with Jane, October 2015)

In the early stages of inquiry-based learning, according to Jane, students tend to resist the inquiry process and want to quickly reach, or be given, the right answer. Their view is that inquiry is akin to problem solving and will always end in a correct answer to the question being explored. Jane describes her students as having a performanceoriented mind-set. These students' experiences in science have made them risk averse and they are reluctant to attempt science tasks where they cannot easily see the final answer or product. For Jane her role is to shift this mind-set towards getting them to focus on being good scientists and acquiring good scientific practices. Once students start engaging with inquiry, their motivation, engagement, and participation levels increase, and they find it more enjoyable.

Jane reports on how, on the one hand, low-attaining students often struggle when confronted with having to design an investigation and seem more willing to just be given a set of instructions. High-attaining students, on the other hand, tend to be more willing to design their own investigations and ask questions, taking responsibility for their learning.

My weaker [low attaining] Y7 they are a lot harder to drag on. Very simply what variable are you going to change? - and they are still really struggling to do anything that is not-just please we are going to follow these instructions. My triple science class [Y11], another really bright class. They were very happy to design their investigations. ....my other Y11, they are kind of middle ability group, were starting to ask questions and starting to take responsibility for their own inquiry skills, so that was really nice to see. (Taken from a discussion with Jane and other teachers on a teacher meeting day, June 2015)

Jane sees her assessment practice, in the context of inquiry, as being focused on gathering evidence of students' thinking that can help her decide what to do next to support further learning. According to Jane, during the informal assessment conversations, she often uses why and how questions to gather evidence of learning. 
Jane reports on the importance of listening and observing before intervening so as to ensure that the teacher will ask appropriate questions. She also reports on the importance of the teacher learning to ask questions or give comments that stimulate thinking rather than provide ready-made answers.

Listen and observe before intervention to ensure appropriate questions. Asking questions and making statements that stimulate thinking as opposed to providing answers. (Taken from a discussion with Jane and other teachers on a teacher meeting day, February 2015)

Jane reported on experiencing some tensions in her assessment practice. The tensions arose as she would have to make decisions on when to let students explore on their own and when to guide them.

When I give feedback I prefer to ask questions because that way they give it to you. To avoid giving them ideas, I find you just start making suggestions and you just push to far in, and often you give them than what they really need and towards the end I am giving more than I was at the beginning because I was very conscious that the design stage had really over run ... but from the point of view of learning about the plan, that wasn't really happening. (Taken from post-lesson (stability of a double decker) interview with Jane, January 2015)

On the one hand, Jane wants students to engage with the investigation independently, without teacher intervention. She reports on having observed that students need time to test different things and come up with new ideas. On the other hand, she feels the pressure of time and curriculum to focus and push their learning forward through teacher guidance and/or intervention.

\section{Features of classroom assessment practice in Jane's lessons}

Classroom observations of Jane's formative assessment practice show that Jane prompts students to reflect on what they are doing and why. Jane circulates around the room listening to students' conversations and observing what they are doing and will often engage in conversations with small groups of students. These conversations tend to be dominated by Jane and although they are driven by her teaching agenda, students' 
participation and ideas are considered. As a consequence, Jane builds on students' answers to implicitly push her teaching agenda forward.

Jane's interactions with her students during an inquiry activity suggest that she has in mind that there are clear "checkpoints" that students need to go through in order to proceed with the inquiry (e.g. adequate control of variables before starting data collection). Her interactions with her students suggest that Jane wants to help them to find these "checkpoints" and ensure that they know what to do to attend to these before moving ahead. To achieve this, she often asks the students to consider whether they have all the information they need to answer their question and to justify their approach.

A detailed analysis of Jane's informal assessment conversations (nine conversations with groups of students over the course of $2 \times 90$ min. lessons) shows that the focus of these conversations is often on conceptual understanding, procedural knowledge, and in some instances about the nature of science. Jane tends to open up a discussion using open-ended questions (e.g. what you think your data is telling you?). Depending on students' responses, Jane will either focus the discussion by building on their answers or will guide students towards an answer by asking follow-up open-ended questions. These are instances when it seems that Jane has a particular "checkpoint" in mind. There are also instances (especially towards the end of the lesson) where Jane gives the answer away to students in order that they reach a certain point in inquiry. Jane seems to face a dilemma between wanting her students to work out what they must do next and feeling compelled to tell them what they need to do when they are struggling with it. In these situations, Jane tends to close down these discussions with a clear set of instructions.

Extract 1, presented on Table 3, is taken from Jane's inquiry lesson on electromagnetism and provides an example of Jane's formative assessment practice in 
the context of informal assessment conversations during an inquiry lesson. Jane starts an open-ended discussion probe students' conceptual understanding of how their results can be explained by theory. As the conversation unfolds Jane's teaching agenda takes over and she closes down the discussion by providing an answer to her own questions.

[Table 3 near here]

\section{James's espoused beliefs}

James's espoused beliefs about inquiry-based learning are associated with learning about the scientific method as a means to test hypotheses and answer questions in a scientific way. He perceives inquiry as a process by which students engage with a question to which they do not have an answer, typically by formulating a hypothesis or a prediction that they investigate by generating their own investigation method. For James, learning through inquiry arises by "Eureka" moments, and he compares students' learning with the process that scientists go through when they make a breakthrough. For him these moments are characterised by insights that arise from engaging in a productive line of thought that eventually bears fruit. According to James these moments are not frequently seen in the classroom and they will emerge from single individuals while the rest of the class is still struggling to grasp a certain idea.

What goes on in the teacher's head is kind of two things. There is a kind of they know the procedure, they probably taught it one way in a number of times, so they are looking for progress, the well-worn path. And, they are also looking for some deviation, something really clever to come out here and there. Some yes! There is a spark, there was a jump there in terms of the student's understanding which might lead to another investigation and might help the teacher understand how they actually progress there. It is looking at two levels and there is a danger there of focusing on the ones who are making this big jump rather than helping other on the mundane path. (Taken from a discussion with James and other teachers on a teacher meeting day, June 2015) 
For James, there is a clear path that determines how a given inquiry should proceed, a path that only the teacher knows in advance. As a consequence, James reports on how he is often searching for students' behaviours and utterances that give him an indication if they are on the right path and about to have a "Eureka" moment, or if they are completely off track. In this context, James seems to have adopted the role of a "shepherd" who makes sure that students get on board on what he perceives to be productive tracks of thought that may give rise to breakthroughs and pulls back students from what he considers to be non-productive lines of thought.

James has reported on experiencing a tension between supporting students who seem to be on a promising track towards having a "Eureka" moment or supporting those who are far away from it.

You'd almost need one person working with a group and reacting and trying to develop the idea as it comes. They weren't able to sort of mediate their own ideas or anything, they just, you know, if someone was coming up with ideas, yes, but very few could come up with, ah, yeah, but what's the problem with that. That's one thing they missed, they literally needed a teacher to say, yeah, but what about this? (Taken from post-lesson (Electromagnets argumentation) interview with James, May 2015)

On the one hand, he perceives his teaching role as making sure that all students are engaged and can make progress. James seems to believe that without his support students will not be able to find and sustain promising tracks of thought. On the other hand, some students find these paths quicker than others, so the difficulty lies in deciding how to support these students while making sure that the other students are making progress as well. According to him current class sizes in the UK (of nearly 30 students for one teacher) hamper the capacity to support each individual student's learning in an adequate way. James's self-reported assessment practices are similar to those reported by Jane. 
[When asked about practice of planning questions in advance] Yes, when I give it thoughts. Why? Can you explain? That wasn't expected? What do you think? [When asked about skills needed to use these conversations for formative purposes] Listening, understanding underneath what they say to spot what else is going on during an in-depth discussion. (Taken from a discussion with James and other teachers on a teacher meeting day, February 2015)

James also reported on being on the lookout for inconsistencies and mistakes in what students say and do, and for evidence that they are stuck and do not know how to proceed.

Without giving them the classic here is your planning sheet, there is your hypothesis, there is your apparatus, they were not very good about phrasing it as a stepwise plan, they were identifying elements, but I had to walk to them and say, but what are you actually going to do? And they said Oh. ...I had to refocus them on that a number of times, but they've managed to get through. I just pointed out well you are going to change something what are you going to measure? What about all the other things? Establish a Fair test. (Taken from post-lesson (Electromagnets) interview with James, February 2015)

Like Jane, James also perceives students' ability to engage with inquiry activities as somehow related to students' attainment levels. He reported on how he would adapt his inquiry lessons, letting high-attainment students engage with more open-ended inquiries while low-attainment students would be given more guided inquiries. Also, like Jane, James has experienced a tension to support students in their thinking process without giving answers away, while helping them to avoid taking a non-productive path or getting stuck.

When you're always going around, you don't want to give them the right answer, but you don't want to leave them just struggling, totally stuck, you try and find a few things and I think perhaps what I was doing was, in some respects, cutting them off, because I was saying, when they were saying, oh, the electricity gets in, I was saying, yeah, but it's insulated, which is in one sense the right thing to say, but had they been allowed to explore the idea of electricity just going in, they may have developed something more themselves then, so maybe I said the wrong thing then, I don't know. (Taken from post-lesson (Electromagnets argumentation) interview with James, May 2015)

For James this tension is also associated with the idea that letting students pursue a nonproductive line of thought will eventually place the teacher is a position of having to say 
"nice idea but wrong!" a position he perceives as unfair towards the students. Time and curriculum pressures were also referred to as factors challenging the implementation of inquiry and assessment conversations. The time pressure was mainly associated with a tension between knowing that students need time to make sense of ideas and concepts, and that at the same time the lesson aims impose a certain rhythm that has to be maintained. Curriculum pressures seemed to be associated with making sure that students do not develop misconceptions when given space and time to think for themselves.

\section{Features of classroom assessment practices in James's lessons}

Classroom observations suggest that James is focused on making sure that students follow a pre-determined track during their inquiry investigations. James tends to circulate around the room engaging in brief conversations with his students. These conversations are typically teacher-led and seem to be driven by his teaching agenda. A detailed analysis of these conversations (nine conversations during $2 \times 60$ min. lessons) shows that the focus of the conversations is mainly on procedural knowledge and some conceptual understanding. James tends to open up a discussion using a combination of open-ended (e.g. what are you trying to do?) and close-ended questions (e.g. how are you going to measure the current?). This is followed by focusing the discussion through building on students' answers and giving corrective or evaluative feedback. James tends to close down these conversations with a clear set of instructions.

Excerpt 2, presented in Table 4, is an example of James's informal assessment conversations with a group of students. This conversation took place during an investigation of the factors influencing the strength of an electromagnet. James seems to be checking what students intend to do in their investigation, and to provide them with 
guidance so that they can conduct their investigation and gather data from it. Although the discussion starts off with an open-ended question, teacher agenda takes over and the discussion is guided by a set of close-ended questions. The focus of the discussion is on procedural knowledge, and there is no exploration of students' conceptual understanding as to why they chose to vary the number of coils and on what their hypothesis is in relation to how that affects the strength of the electromagnet.

[Table 4 near here]

\section{Discussion and conclusions}

The accounts and evidence presented in the results section provide answers to the research questions on teachers' espoused beliefs about inquiry learning, and the features of teachers' classroom assessment practices in relation to inquiry. In this section we present and discuss our interpretation on how these teachers' espoused beliefs influence their teaching and assessment practices, and the impacts that this has on student autonomy and self-regulation, providing an answer to our third research question and placing it in the context of existing literature.

For teachers who are developing an inquiry-based practice, inquiry settings can be quite challenging. Firstly, open-ended inquiries mean that students who are working in groups often follow different research questions and investigation methods. This poses a challenge to the teacher in terms of having to hone in on each group and in a very short period of time evaluate what is going on there and what kind of support that group needs in a particular moment. Secondly, teachers may choose to focus the inquiry lesson on the development of one or two inquiry skills for the entire class, but in reality, teachers often keep a holistic view of both whole class and individual students' 
progress. Regardless of what the focus of the lesson is, teachers are often on the lookout for alternative conceptions, gaps in understanding, as well as in general development of students in terms of acquiring knowledge and skills. So all of this has a marked influence on what teachers notice, and how they respond to it (Cowie, Harrison, \& Willis 2018).

Our findings show that these teachers' espoused beliefs about inquiry and their role as teachers in inquiry lessons are consistent with the way they teach and assess inquiry in the classroom. Jane's adoption of a "facilitator" role results on walking on a tight-rope between promoting students' thinking and discussion (using open-ended questions) and guiding them towards specific answers (using instruction). James's adoption of a "shepherd" role results in guiding students in somehow strict paths of scientific inquiry (using a combination of open- and close-ended questions with evaluative/corrective feedback and instruction).

Author (2009) classifies teachers' classroom pedagogical approaches in three categories: directed, guided, and independent. In a directed pedagogical approach, the student is placed in a position of acceptance of what the teacher is saying, and the classroom talk is dominated by the teacher's questions and comments to direct and summarise learning. In a guided approach, the student is placed as an apprentice in her own learning journey, and the classroom talk is dominated by group and whole classroom discussions. Here the teacher probes what students know and orchestrates the meaning-making of information. In an independent approach, the student is placed in the driving seat of her own learning, and classroom talk is dominated by student-led conversations where the teacher and peers act as resource to one another. In the context of this study, an observation of Jane's teaching and assessment practice suggests that her practice is placed between a directed and a guided approach. James's practice seems 
to fall into a more directed approach. This is consistent with their espoused beliefs about their role as teachers in inquiry lessons.

The way teachers use questioning and feedback in informal assessment conversations contributes to the creation of a learning environment that promotes or hinders students' autonomy and self-regulation. Questioning that promotes a genuine discussion between the teacher and students give the students more autonomy and an opportunity to reflect/pace their learning (Author 2009). In these situations, the discussion agenda is actually shared by the teacher and the student, and if wellorchestrated it can provide a rich-bed of information that will support the teacher in regulating her own teaching practice (e.g. What needs to be addressed? What are the next steps in learning? Should the lesson pace be adjusted?) (Author 2009). Moreover, genuine discussions can trigger students' self-regulation processes. The teacher, by asking questions that probe thinking, encourages articulation of ideas, and promotes meaning-making of an idea within a broader knowledge network, and creates opportunities for the student to reflect on where they are in their learning (e.g. Can I explain my idea clearly to another person? Does this idea make sense to me? How does this it fit into what I already know?).

Both teachers acknowledge that inquiry can promote students' learning autonomy, and that it is important to step back and let students take the driving seat. However, a close observation of their pedagogical approach to teaching and assessment shows that they promote students' learning autonomy to different extents. In the case of James's practice, his adopted "shepherd" role results in creating a learning environment where students have little autonomy to pursue and test their own ideas, and also to negotiate meaning-making with the teacher. In the case of Jane's practice, she tends to encourage students' autonomy but sometimes ends up by taking over. This seems to be 
in accordance with Marshall and Drummond's (2006) findings that teachers who have espoused beliefs about responsibility for the success and failure in promoting students' autonomy would implement classroom activities that promoted student thinking and autonomy. Other teachers, with espoused beliefs on a sense of their personal ownership for their students' learning and a responsibility to help students, tended to implement, in their classroom, heavily guided activities that would restrict students' autonomy.

Both teachers believe that students' ability to engage with inquiry activities is related to students' attainment levels. This seems to suggest that both Jane and James would plan the degree of openness of inquiry lessons according to their students' previous attainment levels, enacting increasingly guided inquiries with lower attaining groups of students. Given that the lessons observed were always with the same group of students this hypothesis could not be investigated.

Both teachers experienced tensions that seem to be rooted in conflicts between espoused beliefs and external pressures. This agrees with Wallace and Kang (2004) findings. Jane and James made explicit reference to the challenge of allowing students to explore their ideas but at the same time keep them on track so that the learning goals can be achieved. They referred to this as keeping the balance between stepping in and stepping out. Time and curriculum pressures were pointed out as hindering the adoption of more inquiry-based learning in science lessons. These tensions have been reported before (Author 2014; Wallace and Kang, 2004). Teachers seem to be torn between giving autonomy to students to learn by trial and error and providing guidance to make sure that students keep on productive learning tracks (Author 2015).

In terms of implications for teacher education and professional development, bringing together evidence about espoused beliefs with incidents of classroom practice is important in developing better understanding of how classroom assessment practice 
in inquiry develops while acknowledging the dilemmas that teacher face as they try to make changes in their practice. Established old routines need to give way to new practice, but for this to happen teachers need time and support to blend in and embed new ideas into their existing practice. Teachers' articulations and justifications of their teaching and assessment practices in the context of inquiry, combined with our own classroom observations give what we perceive to be valuable indications of where these teachers are in their professional learning journey. Effective formative practice requires a complex development of classroom climate and of teacher-student and student-student interactions (Author 2009). Neither of these can be developed quickly nor evolve independently (Author 2013). It is therefore important to provide teachers with a safe space that encourages guided reflection on how teachers' articulations and justifications intersect with classroom practices in order to identify what steps are needed to promote and support teachers' learning journeys towards more student-centered approaches in inquiry.

From a future research perspective, there is a need to explore in greater detail the links between teachers' self-reported beliefs and actual classroom practices by focusing on what teachers' notice during the interactions with students, how they interpret these in light of their own self-reported beliefs, and what they decide to do to support further the learning. There is also a need to study how students experience these classroom interactions, and how those experiences are being made sense of in relation to students' self-reported beliefs about learning and inquiry. Teachers' and students' perspectives then need to be brought together so that a more holistic understanding of teacher-student interactions for learning can be achieved.

\section{Disclosure statement}


No potential conflict of interest was reported by the authors.

\section{Funding}

This work was supported by the European Union's Seventh Framework Programme for research, technological development and demonstration under grant agreement no 321428. 


\section{References}

Anderson, R. D. 2002. "Reforming science teaching: What research says about inquiry." Journal of science teacher education 13(1): 1-12.

Alexander, R. 2006. Towards dialogic teaching: Rethinking classroom talk. York: Dialogos.

Black, P., Harrison, C., Lee, C., Marshall, B. and D. Wiliam 2003. Assessment for Learning- putting it into practice. Buckingham: Open University Press.

Black, P., and D. Wiliam, 1998. "Assessment and classroom learning." Assessment in education 5(1): 7-74. DOI:10.1080/0969595980050102

Black, P., and D. Wiliam, 2009. "Developing the theory of formative assessment." Educational Assessment, Evaluation and Accountability 21(1): 5-31. DOI:10.1007/s11092-008-9068-5

Bryan, L. A. 2003. "Nestedness of beliefs: Examining a prospective elementary teacher's belief system about science teaching and learning." Journal of Research in Science Teaching 40(9): 835-868.

Bryan, L. 2012. "Research on science teacher beliefs." In Second international handbook of science education, edited by Barry J. Fraser, Kenneth Tobin, Campbell J. McRobbie, 477-495. Dordrecht: Springer.

Crawford, B.A. (2000). Embracing the essence of inquiry: New roles for science teachers. Journal of Research in Science Teaching 37: 916-937.

Crawford, B. A. 2007. "Learning to teach science as inquiry in the rough and tumble of practice." Journal of Research in Science Teaching: 44(4): 613-642.

Capps, D. K., and B. A. Crawford. 2013. "Inquiry-based instruction and teaching about nature of science: Are they happening?.” Journal of Science Teacher Education 24(3): 497-526.

Cohen, L., L. Manion, and K. Morrison. 2013. Research Methods in Education. 7th edition. Taylor and Francis.

Cowie, B., Harrison, C. and J. Willis, 2018 "Supporting teacher responsiveness in assessment for learning through disciplined noticing" The Curriculum Journal 29(4): 464-478. DOI:10.1080/09585176.2018.1481442

Harrison, C. 2009. “Assessment for learning: A formative approach to classroom practice". In International handbook of research and development in technology 
education, edited by Alister Jones and Marc de Vries, 449-459. Rotterdam, The Netherlands: Sense.

Harrison, C. 2013. "Collaborative action research as a tool for generating formative feedback on teachers' classroom assessment practice: the KREST Project." Teachers and Teaching: theory and practice 19(2): 202-213.

Harrison, C. 2014. "Assessment of Inquiry Skills in the SAILS Project.” Science Education International 25(1): 112-122.

Harrison, C. 2015. "Assessment for Learning in Science Classrooms.” Journal of Research in Stem Education 1(2): 78-86.

Harrison, C., and S. Howard. 2009. Inside the Primary Black Box. London: GL Assessment.

Heritage, M. 2007. "Formative assessment: What do teachers need to know and do?." Phi Delta Kappan 89(2): 140-145.

Lave, J. 2009. “The practice of learning." In Contemporary Theories of Learning:

Learning Theorists...In Their Own Words, edited by Knud Illeris, 200-208. Abingdon: Routledge.

Lederman, N.G. and D.L, Zeidler, 1987. 'Science teachers' conceptions of the nature of science: Do they really influence teaching behavior?" Science Education 71(5):.721734.

Marshall, B., and M.J. Drummond. 2006. "How teachers engage with assessment for learning: Lessons from the classroom." Research Papers in Education 21(2): 133-149.

Mehan, H. 1979. “'What Time Is It, Denise?’: Asking Knowing Information Questions in Classroom Discourse" Theory into Practice 18: 285-94.

Minner, D. D., A. J., Levy, and J. Century. 2010. "Inquiry-based science instructionwhat is it and does it matter? Results from a research synthesis year 1984 to 2002." Journal of Research in Science Teaching 47(4): 474-496.

Nespor, J. 1987. "The role of beliefs in the practice of teaching." Journal of Curriculum Studies 19(4): 317-328.

Pajares, M. F. 1992. “Teachers' beliefs and educational research: Cleaning up a messy construct." Review of Educational Research 62(3): 307-332.

Roehrig, G. H., and J. A., Luft 2004. “Constraints experienced by beginning secondary science teachers in implementing scientific inquiry lessons”. International Journal of Science Education 26: 3-24. 
Rubie-Davies, C. M. 2007. "Classroom interactions: Exploring the practices of high-and low-expectation teachers". British Journal of Educational Psychology 77(2): 289-306.

Ruiz-Primo, M. A., and E. M Furtak. 2007. 'Exploring teachers' informal formative assessment practices and students' understanding in the context of scientific inquiry." Journal of Research in Science Teaching 44(1): 57-84.

Shavelson, R. L., D. B., Young, C. C., Ayala, P. R., Brandon, E. M., Furtak, M. A., Ruiz-Primo, M. K., Tomita, and Y. Yin. 2008. "On the impact of curriculumembedded formative assessment on learning: a collaboration between curriculum and assessment developers." Applied Measurement in Education 21: 295-314.

DOI:10.1080/08957340802347647

Torrance, H., and J. Pryor, 2001. "Developing formative assessment in the classroom: Using action research to explore and modify theory." British Educational Research Journal 27(5): 615-631.

Wallace, C. S., and N.H. Kang. 2004. "An investigation of experienced secondary science teachers' beliefs about inquiry: An examination of competing belief sets." Journal of Research in Science Teaching 41(9): 936-960.

Wenning, C. J. 2005. "Levels of inquiry: Hierarchies of pedagogical practices and inquiry processes." Journal of Physics Teacher Education Online 2(3): 3-11.

Wenning, C. J. 2007. "Assessing inquiry skills as a component of scientific literacy." Journal of Physics Teacher Education Online 4(2): 21-24. 
Table 1. Details on observed lessons for each teacher.

\begin{tabular}{|c|c|c|c|}
\hline Teacher & Year group & $\begin{array}{l}\text { Lesson } \\
\text { topic/duration/date }\end{array}$ & Inquiry activity details \\
\hline \multirow[t]{2}{*}{ Jane } & \multirow[t]{2}{*}{$\begin{array}{l}\text { Y11 (high } \\
\text { attainment) }\end{array}$} & $\begin{array}{l}\text { Stability of a double } \\
\text { decker bus/ } 90 \text { min./ } \\
\text { January } 2015\end{array}$ & $\begin{array}{l}\text { Preparation } \\
\text { In the previous lesson students were introduced to } \\
\text { the concept of centre of mass. The teacher used a } \\
\text { youtube video to start off a discussion around the } \\
\text { factors that affect the stability of a double decker } \\
\text { bus. In groups of three, students developed their } \\
\text { own research question and investigation plan. } \\
\text { Investigation } \\
\text { In the first half of the lesson, students wrote a } \\
\text { detailed investigation plan, designed and built their } \\
\text { models, tested the models and improved them. The } \\
\text { second half of the lesson was devoted to collecting } \\
\text { and analysing data, and communicating their } \\
\text { findings to the whole class. } \\
\text { Assessment of inquiry skills } \\
\text { Planning investigations. }\end{array}$ \\
\hline & & $\begin{array}{l}\text { Electromagnets/ } 90 \\
\text { min./ February } 2015\end{array}$ & $\begin{array}{l}\text { Preparation } \\
\text { In the begining of the lesson, teacher probed } \\
\text { students' prior knowledge on electromagnetism, } \\
\text { and discussed the factors that influence the strenght } \\
\text { of an electromagnet. The teacher showed a diagram } \\
\text { of an electromagnet. } \\
\text { Investigation } \\
\text { In pairs, students developed their own research } \\
\text { question and drafted an investigation plan. This } \\
\text { was followed by a whole-class discussion around } \\
\text { different investigation plans, and control of } \\
\text { variables. Students revised their investigation } \\
\text { plans, and set to collect and analyse data. } \\
\text { Assessment of inquiry skills } \\
\text { Planning investigations; collecting and analysing } \\
\text { data }\end{array}$ \\
\hline \multirow[t]{2}{*}{ James } & \multirow[t]{2}{*}{$\begin{array}{l}\text { Y11 } \\
\text { (mixed } \\
\text { attainment) }\end{array}$} & $\begin{array}{l}\text { Electromagnets/ } 60 \\
\text { min./ February } 2015\end{array}$ & $\begin{array}{l}\text { Preparation } \\
\text { In the previous lesson, the teacher introduced } \\
\text { electromagnetism and facilitated a whole-class } \\
\text { discussion around the factors that affect the } \\
\text { strenght of an electromagnet. In groups of four, } \\
\text { students drafted an investigation plan. } \\
\text { Investigation } \\
\text { In groups of four, students conducted their } \\
\text { investigations, recording and analysing data. } \\
\text { Assessment of inquiry skills } \\
\text { Planning investigations; recording and analysing } \\
\text { data }\end{array}$ \\
\hline & & $\begin{array}{l}\text { Electromagnets } \\
\text { argumentation/ } \\
60 \text { min./ May } 2015\end{array}$ & $\begin{array}{l}\text { Preparation } \\
\text { In the beggining of the lesson the teacher } \\
\text { demonstrated how to set up an electromagnet, and } \\
\text { recalled students of their investigation on factors } \\
\text { afecting the strenght of an electromagnet. The } \\
\text { teacher provided a set of three sheets to guide } \\
\text { group discussions on what happens inside an } \\
\text { electromagnet when the number of coils around an } \\
\text { iron rod are increased, and why currects affects the } \\
\text { strenght of an electromagnet } \\
\text { Investigation }\end{array}$ \\
\hline
\end{tabular}


In groups of four, students discussed their ideas linking theory with their experimental observations (from the electromagnets lesson conducted two months before)

Assessment of inquiry skills

Linking theory with observations; group work

Table 2. Coding system adapted from Torrance \& Pryor (2001) and Alexander (2006)

used to characterize teacher's actions during informal assessment conversations.

\begin{tabular}{ll}
\hline Codes & Description \\
\hline TD - Divergent & $\begin{array}{l}\text { Questions that open up discussion (how/why?), probing thinking } \\
\text { e.g. What do you think your data is telling you? }\end{array}$ \\
TC - Convergent & $\begin{array}{l}\text { Questions to check if students are on track, focusing the discussion } \\
\text { e.g. Do you think the magnetic field was still getting stronger as you } \\
\text { increased the current? }\end{array}$ \\
TL - Lectures & $\begin{array}{l}\text { Give information through exposition or direct instruction } \\
\text { e.g. The magnetic field is maybe still increasing but not enough to pick up a } \\
\text { whole extra paper clip, ok? it might be able to pick up half of a paper clip. }\end{array}$ \\
TA - Affirms & $\begin{array}{l}\text { Acknowledge/repeat/re-formulate student(s) contribution } \\
\text { e.g. So, you said you are changing the coil... }\end{array}$
\end{tabular}

Table 3. Coded extract from Jane's lesson on Electromagnets (recorded at 20 min to the end of the lesson), and commentary on Jane's formative practice.

\begin{tabular}{|c|c|c|}
\hline Transcript & Codes & $\begin{array}{l}\text { Commentary on Jane's formative } \\
\text { practice }\end{array}$ \\
\hline $\begin{array}{l}\text { [Teacher] This is brilliant (referring to recorded } \\
\text { data), so you've managed to get your current to } \\
\text { go up in fairly regular intervals, you've spaced } \\
\text { them out here to get to the higher ones, ok? And } \\
\text { you are seeing a fairly regular pattern. }\end{array}$ & & \multirow{7}{*}{$\begin{array}{l}\text { The teacher initiates a discussion } \\
\text { with a group of students using an } \\
\text { open-ended question to explore how } \\
\text { students are making sense of the data } \\
\text { that they have collected. One student } \\
\text { responds to this question by } \\
\text { describing the relation between two } \\
\text { experimental variables The teacher } \\
\text { notices that for a given range of } \\
\text { electric current the number of paper } \\
\text { clips that are picked up by the } \\
\text { electromagnet remain the same. The } \\
\text { teacher directs students attention to } \\
\text { this and asks another open-ended } \\
\text { question to probe students ideas on } \\
\text { how this observation can be } \\
\text { explained. However, the teacher } \\
\text { leaves students with very little time to } \\
\text { think about this question (few } \\
\text { seconds), and immediately asks a }\end{array}$} \\
\hline $\begin{array}{l}\text { [Teacher] What is your conclusion? What do } \\
\text { you think your data is telling you? }\end{array}$ & (F TI & \\
\hline $\begin{array}{l}\text { [Student 1] As the current increases the number } \\
\text { of paper clips increases. }\end{array}$ & & \\
\hline $\begin{array}{l}\text { [Teacher] Ok, so because you start at } 0.1 \\
\text { [electric current/amps] and you go to } 1.6 \text {, you } \\
\text { start at } 2 \text { [no. of paper clips] and you go up to } \\
10, \text { yeah }\end{array}$ & $(\mathrm{R}, \mathrm{TL})$ & \\
\hline $\begin{array}{l}\text { [Teacher] what about here where for } 1.15,1.2 \\
\text { and } 1.25 \text { you got } 4 \text { (paper clips) every time? } \\
\text { What is happening here? }\end{array}$ & $(\mathrm{E}, \mathrm{T}$ & \\
\hline $\begin{array}{l}\text { [Teacher] Do you think the magnetic field was } \\
\text { still getting stronger as you increased the } \\
\text { current? }\end{array}$ & $(\mathrm{E}, \mathrm{TC})$ & \\
\hline [Student 1] humm...yes...because...humm.... & & \\
\hline
\end{tabular}




\begin{tabular}{|c|c|c|}
\hline $\begin{array}{l}\text { [Teacher] Ok, let's say mum says here's } 4 \\
\text { shopping bags can you take them upstairs? you } \\
\text { have } 4 \text { shopping bags and you are really } \\
\text { struggling they are really heavy and mum says } \\
\text { can you take another shopping bag? No, cannot } \\
\text { take another bag. ...can you take just one more } \\
\text { apple? yes because it's? }\end{array}$ & $\begin{array}{l}\text { (U,TL, } \\
\text { TC) }\end{array}$ & \multirow{5}{*}{$\begin{array}{l}\text { close-ended question to check } \\
\text { students understanding of the effect } \\
\text { of an increase in electric current in } \\
\text { the intensity of electromagnetic field } \\
\text { The question seems to be intended to } \\
\text { make students think of why, if the } \\
\text { intensity of the electromagnetic field } \\
\text { is increasing, the number of paper } \\
\text { clips picked up remains the same. } \\
\text { Student } 1 \text { seems puzzled and Jane } \\
\text { imediately steps in with a metaphor } \\
\text { for the limit of the resolution of the } \\
\text { experiment, and asks a close-ended } \\
\text { question to check if the student is } \\
\text { following her line of thought. The } \\
\text { student responds to it, and Jane asks } \\
\text { an open-ended question to probe if } \\
\text { students' have any new ideas. } \\
\text { However, Jane waits only a few } \\
\text { seconds, leaving very little time to } \\
\text { students to think about has been } \\
\text { discussed so far, and eventually } \\
\text { provides an explanation for their } \\
\text { experimental observation. }\end{array}$} \\
\hline [Student 1] ... smaller & & \\
\hline [Teacher] smaller, ok & (R,TA) & \\
\hline $\begin{array}{l}\text { [Teacher] So what is happening here? the } \\
\text { magnetic field is maybe still increasing but not } \\
\text { enough to pick up a whole extra paper clip, ok? } \\
\text { it might be able to pick up half of a paper clip. }\end{array}$ & $(\mathrm{U}, \mathrm{TL})$ & \\
\hline $\begin{array}{l}\text { [Teacher] So because your paper clips are } \\
\text { limiting the resolution of your investigation, } \\
\text { therefore you can't tell. All you can tell is when } \\
\text { it gets strong to pick up an extra paper clip. But } \\
\text { if you had it broken up or small paperclips you } \\
\text { might see differences here. }\end{array}$ & $(\mathrm{U}, \mathrm{TL})$ & \\
\hline
\end{tabular}

Codes: E-Elicit, R-Recognise/repeat, U-Use, TA-teacher afirms, TL-teacher lectures, TC-teacher asks close-ended questions, and TD-teacher asks open-ended questions.

Table 4. Coded extract from James's lesson on Electromagnets (recorded at $40 \mathrm{~min}$ to

the end of the lesson), and commentary on James's formative practice.

\begin{tabular}{|c|c|c|}
\hline Transcript & Codes & $\begin{array}{l}\text { Commentary on James's formative } \\
\text { practice }\end{array}$ \\
\hline $\begin{array}{l}\text { [Student 1] Sir! [student calls teacher } \\
\text { attention] }\end{array}$ & & \multirow{12}{*}{$\begin{array}{l}\text { James does not enquire into why } \\
\text { Student } 1 \text { called out his attention. We } \\
\text { do not know if student } 1 \text { had a } \\
\text { question to James, but his calling for } \\
\text { attention suggests that might be the } \\
\text { case. } \\
\text { James initiates a discussion by asking } \\
\text { an open-ended question to probe } \\
\text { what the investigation plan is. } \\
\text { Student } 1 \text { responds, and James } \\
\text { rephrases the question. Student } 1 \\
\text { responds. From this point in the } \\
\text { conversation onwards the discussion } \\
\text { is guided through a series of close- } \\
\text { ended questions and teacher lecturing } \\
\text { to ensure that students are clear about } \\
\text { how to vary one of the variables and } \\
\text { record it in a sistematic way (number } \\
\text { of coils in the electromagnet). }\end{array}$} \\
\hline [Teacher] Ok, what are you trying to do? & (E,TD) & \\
\hline [Student 1] We are going to wrap the coil & & \\
\hline $\begin{array}{l}\text { [Teacher] Ok, what is the thing you are } \\
\text { changing?. }\end{array}$ & $(\mathrm{E}, \mathrm{TD})$ & \\
\hline [Student 1] Oh, we are changing the coil & & \\
\hline $\begin{array}{l}\text { [Teacher] Changing the coil, } \\
\text { more or less, so from one experiment to the } \\
\text { next how much of this [the coil] will you use? }\end{array}$ & $\begin{array}{l}\text { (R,TA) } \\
(\mathrm{U}, \mathrm{TC})\end{array}$ & \\
\hline [Student 1] [Silent] & & \\
\hline $\begin{array}{l}\text { [Teacher] So, you said you are changing the } \\
\text { coil... }\end{array}$ & $(\mathrm{R}, \mathrm{TA})$ & \\
\hline [Student 1] Yeah. & & \\
\hline $\begin{array}{l}\text { [Teacher] So does that mean more next time } \\
\text { or less? }\end{array}$ & $(\mathrm{U}, \mathrm{TC})$ & \\
\hline $\begin{array}{l}\text { [Teacher] I would suggest you wrap some } \\
\text { around, and then some more and some more, } \\
\text { you will have to decide yourself how do you } \\
\text { record it but it is pretty easy }\end{array}$ & $(\mathrm{U}, \mathrm{TL})$ & \\
\hline [Student 2] Could I measure the length? & & \\
\hline
\end{tabular}




\author{
[Teacher] You could measure the length; you (U,TL) \\ could always just count the number of turns, \\ right? either of them are possible. \\ So you decide how you will record it how \\ much wire goes around it but you are going to \\ have to change it right? \\ Codes: E-Elicit, R-Recognise/repeat, U-Use, TA-teacher afirms, TL-teacher lectures, TC-teacher asks \\ close-ended questions, and TD-teacher asks open-ended questions.
}

